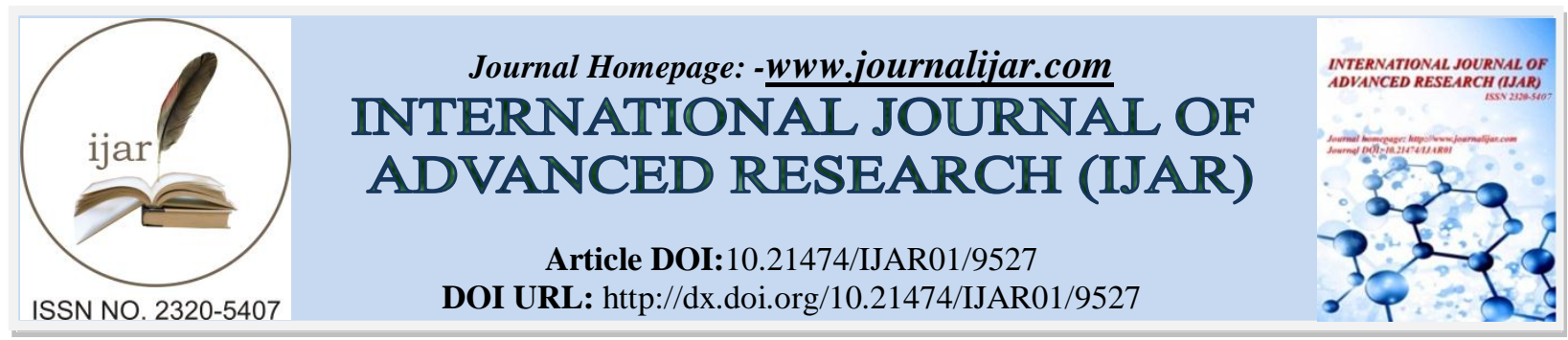

RESEARCH ARTICLE

\title{
TEACHERS' AND LEARNERS' PERCEPTION TOWARDS THE USE OF PODCASTS FOR LEARNING ENGLISH AT THE UNDERGRADUATE LEVEL IN BANGLADESH: AN EMPIRICAL STUDY.
}

Nusrat Zahan Chowdhury ${ }^{1}$ and Dr. Fahmida Haque ${ }^{2}$.

1. Lecturer, Department of English,Faculty of Arts and Social Sciences,Bangladesh University of Professionals, Mirpur Cantonment, Dhaka 1216, Bangladesh.

2. Associate Professor, Department of English, Faculty of Arts and Social Sciences,Bangladesh University of Professionals, Mirpur Cantonment, Dhaka 1216, Bangladesh.

\section{Manuscript Info}

(........................

Manuscript History

Received: 06 June 2019

Final Accepted: 08 July 2019

Published: August 2019

Key words:

Podcast, EFL, Undergraduate Level.

\section{Abstract}

From ancient to modern time, the materials of teaching and learning have been changing with different innovations and scientific revolutions. The use of podcasts or digital audio files as a material of EFL teaching and learning, although a relatively recent phenomenon has now been marked with somewhat a very enthusiastic attitude by its stakeholders. Podcasts have been made and used by teachers and students in many technologically advanced countries across the globe. The present study aims at exploring the EFL learners' and teachers' perception towards the use of podcasting as well as its possibilities and challenges as a material of teaching and learning English at the undergraduate level in Bangladesh. The study has been conducted based on data collected from ten EFL teachers and fifty EFL students randomly selected from one public and one private university of Bangladesh. The research follows a case study approach though it employs both qualitative and quantitative approach by using questionnaires that include only close-ended questions. The data have been analyzed by employing descriptive methods as well as the statistical packages. The analysis of the data reveals the perception of using educational podcasts at the undergraduate level in Bangladesh in teaching EFL. The findings of the study reveals that the perception of EFL students and teachers of undergraduate level about the effectiveness and utility of using educational podcasts in Bangladesh is positive and they are ready to accept the use of podcast enthusiastically. Finally, as a result of the findings, some recommendations in terms of future studies have been conversed in order to ensure the effective use of educational podcasting as a complementary tool to the conventional teaching of EFL at the undergraduate level in Bangladesh.

Copy Right, IJAR, 2019. All rights reserved.
Corresponding Author: NusratZahan Chowdhury. Address: Lecturer, Department of English,Faculty of Arts and Social Sciences,Bangladesh University of Professionals, Mirpur Cantonment, Dhaka 1216, Bangladesh. 


\section{Introduction:-}

\section{Background of the Study}

With the catchphrase of "Digital Bangladesh" and with a view to materializing 'Vision 2021', the Government of Bangladesh is marching forward rapidly with the process of digitalization in all possible aspects of infrastructure and governance. "The nation now, with over 120 million mobile subscribers and 43 million internet subscribers, enjoys the fruits of digitization in numerous areas of activities." (Rahman, 2015). The sector of education, specially the higher education sector, is no exception from this streaming of digitalization. Different features of internet and technology have been extensively used in many government and non-government undergraduate educational institutes. English Language Teaching (ELT) is not beyond the reach of being manipulated by technology and the use of technology is evidently experienced in this field. Digitalization has taken over the traditional scenario of teaching and learning the English language, and a comparatively new approach of digital teaching is podcasting.

Podcasts are audio files which the user can upload through the internet via laptops or smart phones. Those files can then be transferred onto personal computers, laptops, and mobile devices such as MP3 players, mobile phones, and personal digital assistants (PDAs) (Almaqrn\&Alshaheb, 2017).

Today, educational podcasting or the streaming of audio clips through the internet by faculties and students has already proven to be a useful material in many countries in teaching English. However, in our country, in spite of immense digitalization, it is a less utilized tool for teaching. If it could be popularized and made available to our faculties and students and could be well utilized, the learners might have a beneficiary effect by that. However, to introduce podcasting at undergraduate level EFL teaching in our country; it is necessary to explore the perception and expectations of the learners and teachers. This study endeavors to address this issue to suggest ways of making podcasting a complementing tool to ensure a pro-tech teaching-learning environment at the undergraduate level in Bangladesh.

\section{Problem Statement}

Language being a reciprocal phenomenon is better learned with maximum interaction among users. Learners of Bangladesh, particularly, undergraduate level students who are taught English as an auxiliary subject mostly for academic purposes, are not privileged with an adequate amount of real life interactions and exclusive practice outside of the classroom setting. However, with the incorporation of podcasts or audio recordings transmitted via internet, in the existing pedagogy, it is possible to create an effective virtual platform for extensive practice among the students and between the teachers and students. At the same time, podcasting can be an outstanding tool to review the previous class or to announce the lesson plan for the next class. Although students of our country are found to use many different applications and features of internet and recognize the use of podcasting; podcasting is not a very familiar or popular way of teaching English. Why podcasting in Bangladesh remains a less popular tool of EFL teaching, even after more than a decade of its inception, arouses the need of some inquiry and research in the relevant field. The perceptions of both students and teachers towards educational podcasts are required to be explored to find out both the challenges and prospects of using them in EFL teaching. This study aims at understanding the perception of podcasting of the faculties and students at the undergraduate level in teaching English in order to recommend ways to develop teaching tools and materials to promote learning.

\section{Research Gap}

Power and Shrestha while examining the changing landscape of English language teaching methodologies, to explore ways of ICT influences in language learning in our country, describes the English in Action (EiA) project in Bangladesh as, 'a major inter(national) ELT initiative employing mobile technology' (Power \& Shrestha 2010). The project, however, is undertaken to support and bring about change in ELT classroom by incorporating mobile technologies such as media players, smart-phones and laptops within the traditional teaching practices. The researchers describe about EiAs production and evaluation of a range of mobile ICT-enhanced, school based supported Open Distance Learning (iSOL) programs for training English where teachers were supposed to receive materials for their professional development with the use of audio podcasts (enhanced with text and images) (Power \& Shrestha, 2010). When the (EiA) project was designed for the development of secondary level, the present study aims at introducing a similar podcasting system in the undergraduate level from where both the learners and faculty members (teachers) will be benefitted. 


\section{Rationale of the Study}

The research project purposes to understand the viewpoints of EFL teachers and students of the undergraduate level of Bangladesh and desires to get a clear notion about their expectations in introducing a new technology which will enable them to enhance their teaching-learning experience. Introducing podcasting in our socio-cultural context could be befitting for our country because mobile technology has developed in our country rapidly. Due to the affordability and availability of mobile technologies (such as portable radios, mobile phones or MP3 players), the potential opportunity of language learning through mobile phone technology is significant (Power \& Shrestha, 2010). Since, podcasting requires audio recordings to be downloaded in any device which supports the audio recording player; it will be feasible to adapt educational podcasting in EFL teaching in the context of Bangladesh. Now, once the perception and expectations of educational podcasting from its stakeholders (importantly faculties and students) are known, and the possible challenges and glitches are stated, it would be possible to familiarize and incorporate educational podcasting (widely used in many technologically advanced countries but narrowly used in our country for EFL purposes) which might be a very useful and potential apparatus of teaching English in the undergraduate level in our country.

\section{Research Objectives \\ Broad Objective}

The general objective of this project is -

To understand the perception of EFL students and teachers of undergraduate level about the effectiveness and utility of using educational podcasts in Bangladesh.

\section{Specific Objectives}

This study on the perception of podcasts comprises of the following objectives -

1. To explore if podcasts can be a facilitating tool in teaching EFL at the undergraduate level.

2. To address the effectiveness of educational podcasting as an EFL teaching and learning tool in Bangladesh.

3. To trace out the skill(s) of English language which is/are assisted by the use of podcasts and to what extent they are aided by the use of educational podcasts.

4. To define the possibilities of using podcasts as an assistive tool in teaching English at the undergraduate level.

5. To pave ways to create effective educational podcasts to enhance smart EFL teaching/learning experiences at the undergraduate level in Bangladesh.

\section{Theoretical Framework \\ Podcasting}

The Oxford English Dictionary defines podcast as 'A digital audio file made available on the Internet for downloading to a computer or mobile device, typically available as a series, new installments of which can be received by subscribers automatically'. According to Geoghegan and Klass (2007) a podcast is a downloadable audio or video content delivered to one's computer or portable media player from the internet. The term was coined by blending the words iPod and broadcast and the term was not heard until 2004. Although the device iPod is embedded in the etymology of podcast, it does not require someone to have an iPod to listen to or produce podcasts. All it needs is a computer or mobile phone with an internet connection, a web browser or pod-catcher and headphone or speaker. It uses RSS (Really Simple Syndication, an XML-based transmission system), news or other information that can be automatically received via specific software. Individuals can choose and subscribe to the podcasting sites according to their choice. When there is a new file on the subscribed site, that file is automatically downloaded by the software to the mobile device or the computer. The downloaded podcast then can be listened to at anytime, anywhere according to the desire of the subscriber. Subscription is the only thing that is required to receive the latest uploaded podcast. It is thus automatic, easy to control, portable and always available (Geoghegan and Klass, 2007). When there are a number of Podcast contents in the internet, individuals including EFL learners and teachers can create their own podcasts by recording, encoding, and uploading them onto the internet for others to listen to them as it is free and available for everyone.

\section{Literature Review \\ Effectiveness and Attitudes towards Podcasting}

Studies have shown that the use of educational podcasts effects learners in positive ways. Different researches and surveys undertaken by different researchers found the positive attitude of teachers and students towards educational podcasts. Gribbins (2007) conducted a survey in early 2006 on graduate Management Information System students of University of Illionis at Springfield to investigate students' potential acceptance of podcasting as an educational 
tool where $70 \%$ students had positive responses towards the usefulness of podcasting as an educational tool. RobiDarwis's (2016) study finds that students have a positive attitude towards the use of podcasts in learning English for their dexterity in using them. Ince (2015) investigated Twenty-eight EFL learners studying at the School of Foreign Languages of Bülent Ecevit University, Ankara, Turkey and found that the learners generally had positive opinions about this technology. Nicole Ortloff (2016) claims in a study that 65\% students listened or watched podcasts multiple times for a better understanding of their subject matters. Evans (2008) claims the same that podcasts are more effective review tools than textbooks and learners are more efficient in using podcasts than their own notes to learn. A yearlong project on producing podcast by a group of second year undergraduate students of Charles Stuart University shows that student involvement and engagement in the production of content for podcasts is a positive learning experience. The analysis of the focus group discussions demonstrated that producers reflected on the activity and viewed it as a form of experiential learning that yielded positive gains in terms of technical and generic skills (Chan, Lee and McLoughlin, 2006). The study of Fernandez, Simo, \&Sallan, (2009) agreed with the positive attitude towards podcasting where they argue podcasting as a powerful tool which serves as a complement to the traditional resources as a tool when at the same time they maintain that it cannot be a substitute for them. Darwis (2016) also agreed to the account that podcast is a useful tool for learning English.

\section{Skill Development through Podcasting}

Using educational podcasts have significant effect on particular skill development, especially language skills. Almaqrn, \&Alshabeb (2017) contend that podcasts facilitate proper pronunciation. Since traditional podcast is meant to be produced for listening, and are created by speaking, it is likely to facilitate productive skills as pronunciation and speaking as well as aid receptive ones as auditory or listening skills. Darwis (2016) also claims that students' listening skills are enhanced by listening to podcasts.

\section{Potentials of Using Podcasts}

A number of studies have shown that the use of educational podcasts effect learner in positive ways. Evans (2008) argues that, Podcasting has substantial prospective as an advanced education tool for adult learners in Higher Education and the students enjoy the autonomy of choosing when and where they will use it. Rostami, Azarnoosh, \&Abdolmanafi-Rokni, (2017) agreed to the same stating that, podcasting enables learners with the brilliant opportunity of creating and listening to audio files from anywhere they want, anytime they want and in what way they want. Podcasting being a portable audio file which can be created and transmitted over the internet, through subscription, can be downloaded to any electronic device which supports audio media file. Thus it gives students the autonomy of selecting the content, time and place according to their choice. Rostami, Azarnoosh, \&AbdolmanafiRokni (2017) find podcasting a great tool to motivate language learners in the classrooms. They suggest that curriculum developers and material developers can sue podcasts to improve students' learning by increasing their motivation level.

\section{Challenges}

In spite of countless utilities and positive attitudes of the stakeholders towards podcasting, some challenges and limitations have been found by several studies. Maag (2006) maintains the following potential challenges of using podcasting technologies: students' adoption of the educational aspect of the device, technical support from university instructional technology departments (e.g. server space, bandwidth, maintenance etc.), and faculty member buy-in of the use of technology. However, he argues that if educators understood the generation of students they are teaching, perhaps they would recognize that ubiquitous podcasting may assist learners and educators to share a voice and enhance communication. Rostami, Azarnoosh\&Abdolmanafi-Rokni (2017) contend that using podcasts may cause the isolation of students from their peers. However, if the instructors can ensure that the learners create their own podcast and share their ones with the rest of the class this problem can be overcome. Another problem of podcasting found by some researchers is that listening of long podcasting can be sometimes tedious and boring. Darwis (2016) claims that students seem to lose focus when listening to podcasts with the length of more than 5 minutes. Ortloff (2016) argue that students learn best when information is provided in chunks or short segments. So podcasts, to get the maximum benefit, should not be too long. Otherwise students will end up being bored and lose concentration listening to long audio clips. İnce's (2015) study finds that students do not listen to podcasts outside or while multitasking and he contends that this is how they ignore the mobility feature of podcasting. 


\section{Methodology:-}

This study follows a case study design. The issue addressed in this study is to explore the understanding of podcasts and its acceptance to the faculties and students of EFL at the undergraduate level of Bangladesh. Also, in order to gain a deeper analysis, the problems that the students encountered in using podcast were investigated. The participants involved in this study are fifty EFL students randomly selected by a pilot study previously done from one public and one private university of Bangladesh who are already familiar with internet technology. However, all students should not have any experience in using podcasts for learning English before. At the beginning of the study, the participants were informed about podcast and where to get it. The students and teachers were given a list of podcasts where they can download clips from. The students were informed about how to get podcasts from the internet on their desktop, laptop, iPhone and other smartphones. Every week, the participants' activity of listening to podcasts has been followed up by the researcher. Then, after three weeks of students' activity in listening to podcast, the questionnaires have been distributed to collect the data. To investigate attitudes, perceptions and opinions, closeended questionnaires have been used in this study. The analysis of the data then was elaborated descriptively, since the characteristic of a case study is to describe and explain an event or phenomena systematically.

\section{Sampling}

The study takes place in Bangladesh University of Professionals and East-West University. Bangladesh University of Professionals (BUP), the $29^{\text {th }}$ public university of the country, is situated at Mirpur Cantonment, a very prominent and distinguished area of the capital city Dhaka. The latter one is a renowned private university located at Aftabnagar, Rampura on ProgotiSarani, Dhaka. The population of the study is all the EFL teachers and students of undergraduate level of Bangladesh. However, this study takes its respondents from one public university BUP and a private university EWU. 10 EFL teachers and $50 \mathrm{EFL}$ students have been randomly selected as the respondents of this research. The study has used the convenient sampling technique to select its participants. Through a pilot study conducted on 20 teachers and around 400 students, 5 EFL teachers and 25 EFL students from different departments were selected from each university to respond to the questionaaire.

\section{Research Instruments}

The study has employed questionnaires as the only data collection method. Two different questionnaires intended for teachers and students are comprised of 18 statements relevant to the research objectives on which the teachers have the choice to agree or disagree through five options- 'strongly agree', 'agree', no opinion', 'disagree', 'strongly disagree'. The items of the questionnaires are concerned with Podcasts as a facilitating tool (Item no 1, 2, 3, 4), Effectiveness of Podcasting (Item no. 5, 6, 7), Skills assisted by educational Podcasts (Item no. 8, 9, 10, 11, 12, 13), Possibilities of using Podcasts as an assistive tool in teaching English (Item no. 14,15), and Possible limitations (Item no. 16, 17,18).

\section{Data Collection}

Ten EFL teachers and fifty EFL students from two undergraduate level institutes are the respondents who provided primary data by responding to the questionnaires. The questionnaires were distributed to teachers and students by email, social media platforms and by in person correspondence at their convenience for the data collection to be rapid. The desired data was collected from the mentioned setting from September 2018 to February 2019.

The data were analyzed by employing the descriptive and contextual methods. In addition, the teachers' and the students' responses to the questionnaires were computed and analyzed using the SPSS program module. The statistical measurement used here included means and standard deviations for each item of the questionnaire. The statements assessing the responses of the participants were adopted through a five point Likert Scale.

\section{Data Analysis:-}

Analysis of Data Collected from Students

Table 5.1.1:-Mean and Standard Deviation of the Student Questionnaire

\begin{tabular}{|l|l|l|l|}
\hline No & Items & Mean & Standard Deviation \\
\hline 1 & $\begin{array}{l}\text { I believe that podcast can be used as a complementary } \\
\text { tool with traditional teaching of EFL at the } \\
\text { undergraduate level in Bangladesh. }\end{array}$ & .834 \\
\hline 2 & $\begin{array}{l}\text { Podcast can offer an enormous opportunity to enhance } \\
\text { teaching-learning experience. }\end{array}$ & 2.26 & 1.084 \\
\hline
\end{tabular}




\begin{tabular}{|c|c|c|c|}
\hline 3 & $\begin{array}{l}\text { It is possible to get an exposure to native/native-like } \\
\text { situational and academic English environment with the } \\
\text { use of podcasting. }\end{array}$ & 2.00 & .948 \\
\hline 4 & $\begin{array}{l}\text { Learning could be made entertaining integrating } \\
\text { podcasting with it. }\end{array}$ & 2.04 & 1.029 \\
\hline 5 & $\begin{array}{l}\text { My performance could be improved with the integration } \\
\text { of podcasting into the curriculum. }\end{array}$ & 2.04 & 1.068 \\
\hline 6 & $\begin{array}{l}\text { Podcasting would be much effective than other } \\
\text { technologies as it is easily accessible and affordable. }\end{array}$ & 2.40 & 1.107 \\
\hline 7 & $\begin{array}{l}\text { Podcasting would be effective in Bangladesh because of } \\
\text { the ubiquitous mobile technology. }\end{array}$ & 2.10 & .814 \\
\hline 8 & Podcasts would enhance my skills of listening. & 1.66 & .717 \\
\hline 9 & Podcast listeners are better speakers. & 2.90 & 1.199 \\
\hline 10 & Podcast can enrich my vocabulary. & 2.14 & .881 \\
\hline 11 & Podcasts contributes to developing my writing style. & 2.32 & .978 \\
\hline 12 & Podcasts help me have better pronunciation. & 1.70 & .763 \\
\hline 13 & Podcasts affect my reading skills in a positive way. & 3.12 & 1.206 \\
\hline 14 & $\begin{array}{l}\text { It is possible to create and host podcasts by joint } \\
\text { collaboration of the teachers and the students to enhance } \\
\text { learning. }\end{array}$ & 2.00 & .808 \\
\hline 15 & $\begin{array}{l}\text { Podcasts will be able to engage me actively in the } \\
\text { learning activity. }\end{array}$ & 2.20 & .948 \\
\hline 16 & $\begin{array}{l}\text { I found the native intonation and pitch difficult to get } \\
\text { while listening to podcasts at the outset. }\end{array}$ & 2.12 & 1.100 \\
\hline 17 & $\begin{array}{l}\text { The diversity of the subjects of podcasting seems } \\
\text { misleading. }\end{array}$ & 2.36 & 1.005 \\
\hline 18 & Lengthy podcasts often induce boredom. & 2.24 & 1.001 \\
\hline
\end{tabular}

Analysis of Data Collected from Teachers

Table 5.2.1:-Mean and Standard Deviation of the Teacher Questionnaire

\begin{tabular}{|l|l|l|l|}
\hline No & Item & Mean & $\begin{array}{l}\text { Standard } \\
\text { Deviation }\end{array}$ \\
\hline 1 & $\begin{array}{l}\text { I believe that podcast can be used as a complementary tool with } \\
\text { traditional teaching of EFL at the undergraduate level }\end{array}$ & 1.60 & .699 \\
\hline 2 & $\begin{array}{l}\text { Podcast can offer an enormous opportunity to enhance teaching- } \\
\text { learning experience. }\end{array}$ & 2.20 & 1.135 \\
\hline 3 & $\begin{array}{l}\text { It is possible to give students exposure to native/native-like } \\
\text { situational and academic English environment with the use of } \\
\text { podcasting. }\end{array}$ & 1.90 & .316 \\
\hline 4 & $\begin{array}{l}\text { Teaching could be made entertaining integrating podcasting with } \\
\text { it. }\end{array}$ & 2.30 & .823 \\
\hline 5. & $\begin{array}{l}\text { The performance of a student could be improved with the } \\
\text { integration of podcasting into the curriculum. }\end{array}$ & 1.80 & .789 \\
\hline 6 & $\begin{array}{l}\text { Podcasting would be much effective than other technologies as it } \\
\text { is easily accessible and affordable. }\end{array}$ & 2.20 & .919 \\
\hline 7 & $\begin{array}{l}\text { Podcasting would be effective in Bangladesh because of the } \\
\text { ubiquitous mobile technology }\end{array}$ & 2.00 & .943 \\
\hline 8 & Podcasts enhances students'skills of listening & 1.60 & .516 \\
\hline 9 & Students who listen to podcast are better speakers. & 3.10 & 1.197 \\
\hline 10 & $\begin{array}{l}\text { Podcast enriches the vocabulary of the students } \\
\text { Podcasts contributes to developing the writing style of the } \\
\text { students }\end{array}$ & 2.10 & .876 \\
\hline 11 & Podcasts help students have better pronunciation & 1.40 & .265 \\
\hline 12 & Podcasts affects the reading skills of the students. & 3.20 & 1.135 \\
\hline 13 & & \\
\hline
\end{tabular}




\begin{tabular}{|l|l|l|l|}
\hline 14 & $\begin{array}{l}\text { It is possible to create and host podcasts by the teachers and the } \\
\text { students to enhance learning }\end{array}$ & 1.80 & .632 \\
\hline 15 & $\begin{array}{l}\text { Podcasts will be able to engage students actively in the learning } \\
\text { activity. }\end{array}$ & 2.50 & 1.354 \\
\hline 16 & $\begin{array}{l}\text { Students might find the native intonation and pitch difficult to get } \\
\text { while listening to podcasts at the outset. }\end{array}$ & 2.10 & .876 \\
\hline 17 & The diversity of the subjects of podcasting might be misleading & 2.10 & .876 \\
\hline 18 & Lengthy podcasts might induce boredom. & 1.90 & .994 \\
\hline
\end{tabular}

The presentations and discussion of the data mentioned above are all related to the research questions and objectives. The first objective was to explore if podcasting can be a facilitating tool in EFL teaching. Items no. 1, 2, 3 and 4 for both teachers' and students' questionnaires are related to this objective. The response of both the teacher and the students are found to be positive towards this. More than $80 \%$ students and teachers are found to admit that that podcast can be used as a complementary tool with traditional teaching of EFL at the undergraduate level in Bangladesh. Almost $70 \%$ teachers and students have come to an agreement that podcasts can play a vital role in enhancing the teaching-learning experience. Both teachers and students find that podcasts can give students exposure of native like pronunciation. Teachers are more optimistic about the ability of podcasts giving students native like exposure of English language as $100 \%$ of all the respondents have shown their agreement to two different extents (strongly agree and agree) with this statement. More than $70 \%$ teachers and students share their agreement on the statement that teaching could be entertaining by the use of podcasts. So overall, according to the perception of the EFL teachers and students who have taken part in this research, podcasting can be a facilitating tool in EFL teaching. This finding is consistent with the study of Darwis (2016) which claims that most of the students perceive podcasts in a positive way and it can be used as an accessible tool for students to be exposed to English language.

The second objective is to address the perceived effectiveness of podcasting by EFL teachers and students in Bangladesh. Items no. 5, 6 and 7 of both questionnaires are related to this objective. $80 \%$ teachers and $78 \%$ students believe that their performance could be improved with the integration of podcasting into the curriculum. $60 \%$ students and $70 \%$ teachers think that podcast would be effective because it is affordable and accessible. And finally in Bangladesh, because of the ever-present mobile technology, podcasting would be effective, is agreed by both teachers and students respectively at a rate of $80 \%$ and $74 \%$. Therefore, the research argues that in the context of Bangladesh, podcasting would be an effective tool for EFL teaching. The third objective of this research is to assess the skills assisted by the use of podcasting and is addressed by item no. 8, 9, 10,11,12 and 13. This study by two questionnaires for students and teachers finds that podcast helps students mostly with listening and pronunciation. Also, it affects the reading skills and vocabulary to some extent. However, a limited number of respondents think that it can affect the reading and writing skills too. Overall, almost $90 \%$ respondents agreed that podcasting aid listening, and pronunciation, and it aids reading, writing and speaking to some extent.

The fourth objective- possibilities of using podcasts as an assisting tool has been evaluated by item no. 14 and 15 . Although both teachers and students admit that it is possible to create and host podcasts by the teachers and the students to enhance learning, teachers are more enthusiastic (90\%) about it than that of the students (76\%). The statement that podcasts will be able to engage students actively in the learning activity has been supported by $42 \%$ teachers and $60 \%$ students. It can be interpreted as teachers and students are enthusiastic about creating podcasts of their own but teachers are less confident about podcasts' ability to engage students actively in the learning.

With a view to paving ways to create effective educational podcasts to enhance smart EFL teaching/learning experience in the undergraduate level in Bangladesh which is the fifth objective, this research tries to figure out the potential challenges of introducing podcasting to the students. Item no. 16, 17 and 18 of both questionnaires are related to this. Almost $80 \%$ students and teachers think that the native intonation and pitch is difficult to get while listening to podcasts at the beginning. There are quite a range of podcasts on varied matters. However, while $60 \%$ students think that diversity of the subjects of podcasting might be misleading, $60 \%$ students think so. About the length of podcasts both students and teachers think that lengthy podcasts might be misleading. So, the possible problems found are, struggling to get the native intonation and pitch, podcasts on varied subjects and their length. The present study on ten EFL teachers and fifty EFL students from one public and one private university of Bangladesh is designed to know the perception of EFL students and teachers of undergraduate level about the 
effectiveness and utility of using educational podcasts here. In order to explore this objective, the study aims at focusing at the understanding and outlook of EFL teachers and students towards podcasts and tries to explore if podcasts can be a facilitating tool in teaching EFL in undergraduate level. The study also addresses the perceived effectiveness of educational podcasting as an EFL teaching and learning tool in Bangladesh, language skill(s) assisted by podcasting as perceived by EFL teachers and students, possibilities of using podcasts as an assisting tool in teaching English in undergraduate level to suggest recommendations with a view to incorporating podcasting as an educational tool.

\section{Findings:-}

The research revealed that both the teachers and the students are positive towards the adoption of podcasting in traditional teaching methods. More than $80 \%$ students and teachers are found to admit that podcasts can be used as a complementary tool with traditional teaching of EFL at the undergraduate level in Bangladesh. According to the perception of the EFL teachers and students who have taken part in this research, podcasting can be a facilitating tool in EFL teaching. This finding matches with the finding of Darwis's (2016) study which claims that most of the students perceive podcasts in a positive way and it can be used as an accessible tool for students to be exposed to the English language.

The research finds that in the context of Bangladesh, podcasting could improve the performance of the students. It is affordable and accessible because of the available mobile technology.

This study also figures out that EFL students and teachers think that podcast helps students mostly with listening and pronunciation. Also, it affects the reading skills and vocabulary to some extent. However, a small number of respondents think that it can affect the reading and writing skill too. Overall, almost $90 \%$ respondents agreed that podcasting aids listening skills, pronunciation, and it aids reading, writing and speaking,even if to a little extent.

The study further finds that, teachers are more enthusiastic than the students about hosting podcasts by their own, although both groups admit that it is possible to create and host podcasts by the teachers and the students to enhance learning. Students are found to be optimistic about the podcasts' ability to engage themselves in learning while teachers' degree of accordance with them is less significant. However, the study finds that podcasting has significant possibilities of being used as an assisting tool at the undergraduate level EFL teaching in Bangladesh.

As potential challenges, this study marks the problem of students' struggling with intonation and tone at the beginning and the likelihood of getting bored by the lengthy podcasts. However, almost half of the respondents find the range of varied topics misleading, nonetheless, the other half think otherwise.

So, overall, the findings of the study reveal that the perception of EFL students and teachers of undergraduate level about the effectiveness and utility of using educational podcasts in Bangladesh is positive and they are ready to accept this enthusiastically.

\section{Recommendations:-}

Based on the findings, some recommendations may be intimated in order to enhance the EFL teaching-learning experience. Firstly, podcasting can be used as an aiding tool with the traditional approach of teaching English. There are a number of podcasts available in the internet. Those podcasts can be used as teaching material by the teachers. Learning would be made entertaining by this, since this study has shown the interest of the students to accept podcasts as study material. To teach listening and pronunciation and to give students an exposure to native English language, podcasting can be a great apparatus.

Secondly, teachers, at the beginning, can suggest and recommend useful podcasts for students so that students do not have to struggle finding podcasts in the midst of numerous existing podcasts in the vastness of the internet. Once students get used to know about the useful and educational podcasts, eventually they will be able to choose podcasts according to their own taste and needs.

Thirdly, other than relying on the readymade available podcasts, teachers and students can host their own podcasts. It is possible to create and upload customized podcasts by the teachers and students according to the learners' needs. Both teachers and learners can collaborate to produce podcasts of their own and use them in the best possible way. 
Finally, while incorporating podcasts in EFL teaching practice, it has to be kept in mind that they should not be very long, as the study found that lengthy podcasts might induce boredom. However, the length of the podcasts that were considered boring is not revealed by the study and further studies might be conducted on this issue.

\section{Suggestions for further Study}

There are many issues worthy of further attention that stemmed from this research:

1. Extent of skills facilitated by podcasting.

2. Types of podcasts (audio or video) preferred by teachers and students.

3. What should be the optimum length of podcasts?

4. The effectiveness of podcasting after being incorporated in the traditional teaching practices.

\section{References:-}

1. Almaqrn, R. and Alshabeb, A. (2017). EFL Learners' Attitudes towards the Proper Pronunciation of English and Podcasts as a Facilitator of Proper Pronunciation. Arab World English Journal, 8(1), pp.208-219.

2. Chan, A., Lee, M. and McLoughlin, C. (2006). Everyone's Learning with Podcasting: A Charles Sturt University Experience. In: 23rd annual ASCILITE Conference: Who's learning? Whose technology?. [online] Sydney, pp.111-120. Available at:http://ascilite.org/

3. conferences/sydney06/proceeding/pdf_papers/p171.pdf [Accessed 6 Jul. 2019].

4. Darwis, R. (2016). Students' Perception Towards the Use of Podcast in Learning English: A Case Study of the Second Grade Students at one High School in Bandung. Journal of English and Education, 4(2), pp.80-100.

5. Derakhshan, A., Salehi, D. and Rahimzadeh, M. (2015). Computer-Assisted Language Learning (Call): Pedagogical Pros and Cons. International Journal of English Language and Literature Studies, 4(3), pp.111-120.

6. Evans, C. (2008). The Effectiveness of M-learning in the Form of Podcast Revision Lectures in Higher Education. Computers \& Education, 50(2), pp.491-498.

7. Fernandez, V., Simo, P. and Sallan, J. (2009). Podcasting: A New Technological Tool to Facilitate Good Practice in Higher Education. Computers \& Education, 53(2), pp.385-392.

8. Gribbins, M. (2007). The Perceived Usefulness of Podcasting in Higher Education: A Survey of Students' Attitude and Intention to Use. In: MWAIS 2007. [online] Springfield: AIS Electronic Library. Available at: https://pdfs.semanticscholar.org/721e/66ab48a94f6a91f40b31f557743039fb6149.pdf [Accessed 14 Jul. 2019].

9. Hashim, H., Md. Yunus, M., Amin Embi, M. and Mohamed Ozir, N. (2017). Mobile-assisted Language Learning (MALL) for ESL Learners: A Review of Affordances and Constraints. SainsHumanika, 9(1-5), pp.4550 .

10. İnce, H. (2015). EFL Learners' Perceptions of Educational Podcasting. Graduate. IhsanDogramaciBilkent University.

11. Kukulska-Hulme, A. and Shield, L. (2008). An Overview of Mobile Assisted Language Learning: From Content Delivery to Supported Collaboration and Interaction. ReCALL, 20(3), pp.271-289.

12. Maag, M. (2006). Podcasting and MP3 Players. CIN: Computers, Informatics, Nursing, 24(1), pp.9-13.

13. McKinney, D., Dyck, J. and Luber, E. (2009). iTunes University and the Classroom: Can Podcasts Replace Professors? Computers \& Education, 52(3), pp.617-623.

14. Ortloff, N. (2016). Faculty and Student Perceptions of Podcasting: Empirical Evidence from

15. Four Higher Education Institutions.Business Education \& Accreditation, 8(1), pp.47-56.

16. Rahman, L. (2015). Digital Bangladesh: Dreams and Reality. [online] The Daily Star. Available at: https://www.thedailystar.net/supplements/24th-anniversary-the-daily-star-part-1/digital-bangladesh-dreamsand-reality-73118 [Accessed 9 May 2019].

17. Power, T. and Shrestha, P. (2009). Is there a Role for Mobile Technologies in Open and Distance Language Learning? An Exploration in the Context of Bangladesh. In: 8th International Language and Development Conference.

18. Power, T. and Shrestha, P. (2010). Mobile Technologies for (English) Language Learning: An Exploration in the Context of Bangladesh. In: IADIS International Conference: Mobile Learning 2010.

\section{Appendices \\ Appendix A \\ Teacher Questionnaire \\ Dear Colleague,}


On the following statements, some people may agree and some others disagree. Therefore, there is no right or wrong answer. Please convey your opinions by putting a tick mark $(\checkmark)$ in only one box against each statement which best depicts the extent to which you agree or disagree with that statement.

Thank you very much for your generous cooperation in advance.

\begin{tabular}{|c|c|c|c|c|c|c|}
\hline $\begin{array}{l}\text { Serial } \\
\text { no. }\end{array}$ & Statement & $\begin{array}{l}\text { Strongly } \\
\text { Agree (1) }\end{array}$ & Agree (2) & $\begin{array}{l}\text { No Opinion } \\
\text { (3) }\end{array}$ & $\begin{array}{l}\text { Disagree } \\
\text { (4) }\end{array}$ & $\begin{array}{l}\text { Strongly } \\
\text { Disagree } \\
\text { (5) } \\
\end{array}$ \\
\hline \multicolumn{7}{|c|}{ Podcast as a facilitating tool } \\
\hline 1. & $\begin{array}{l}\text { I believe that podcast can be } \\
\text { used as a complementary tool } \\
\text { with traditional teaching of } \\
\text { EFL at the undergraduate level } \\
\text { in Bangladesh. }\end{array}$ & & & & & \\
\hline 2. & $\begin{array}{l}\text { Podcast can offer an enormous } \\
\text { opportunity to enhance } \\
\text { teaching-learning experience. }\end{array}$ & & & & & \\
\hline 3. & $\begin{array}{l}\text { It is possible to give students } \\
\text { exposure to native/native-like } \\
\text { situational and academic } \\
\text { English language usage with } \\
\text { the use of podcasting. }\end{array}$ & & & & & \\
\hline 4. & $\begin{array}{ll}\text { Teaching could be made } \\
\text { entertaining } & \text { integrating } \\
\text { podcasting with it. } & \end{array}$ & & & & & \\
\hline \multicolumn{7}{|c|}{ Effectiveness of Podcasting } \\
\hline 5 & $\begin{array}{l}\text { The performance of a student } \\
\text { could be improved with the } \\
\text { integration of podcasting into } \\
\text { the curriculum. }\end{array}$ & & & & & \\
\hline 6. & $\begin{array}{l}\text { Podcasting would be much } \\
\text { effective than } \\
\text { technologies as it is easily } \\
\text { accessible and affordable. }\end{array}$ & & & & & \\
\hline 7. & $\begin{array}{l}\text { Podcasting would be effective } \\
\text { in Bangladesh because of the } \\
\text { ubiquitous mobile technology. }\end{array}$ & & & & & \\
\hline \multicolumn{7}{|c|}{ Skills assisted by educational podcast } \\
\hline 8. & $\begin{array}{l}\text { Podcasts enhances students' } \\
\text { skills of listening. }\end{array}$ & & & & & \\
\hline 9. & $\begin{array}{l}\text { Students who listen to podcast } \\
\text { are better speakers. }\end{array}$ & & & & & \\
\hline 10. & $\begin{array}{l}\text { Podcast enriches the vocabulary } \\
\text { of the students. }\end{array}$ & & & & & \\
\hline 11. & $\begin{array}{l}\text { Podcasts contributes to } \\
\text { developing the writing style of } \\
\text { the students. }\end{array}$ & & & & & \\
\hline 12. & $\begin{array}{l}\text { Podcasts help students have } \\
\text { better pronunciation. }\end{array}$ & & & & & \\
\hline 13. & $\begin{array}{l}\text { Podcasts affects the reading } \\
\text { skills of the students. }\end{array}$ & & & & & \\
\hline
\end{tabular}




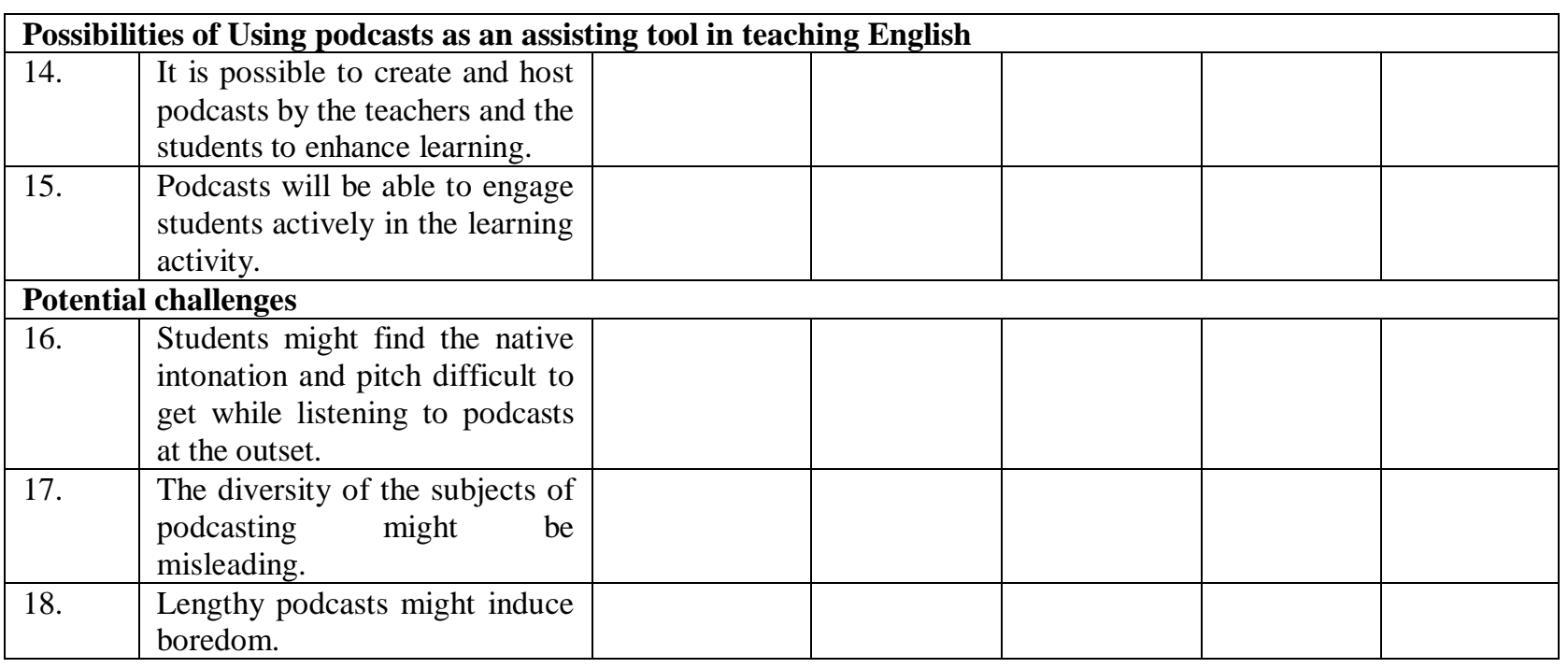

\section{Appendix B}

\section{Student Questionnaire}

Dear Student,

On the following statements, some people may agree and some others disagree. Therefore, there is no right or wrong answer. Please convey your opinions by putting a tick mark $(\checkmark)$ in only one box against each statement which best depicts the extent to which you agree or disagree with that statement.

Thank you very much for your generous cooperation in advance.

\begin{tabular}{|c|c|c|c|c|c|c|}
\hline $\begin{array}{l}\text { Serial } \\
\text { no. }\end{array}$ & Statement & $\begin{array}{l}\text { Strongly } \\
\text { Agree (1) }\end{array}$ & Agree (2) & $\begin{array}{l}\text { No Opinion } \\
\text { (3) }\end{array}$ & $\begin{array}{l}\text { Disagree } \\
\text { (4) }\end{array}$ & $\begin{array}{l}\text { Strongly } \\
\text { Disagree } \\
\text { (5) }\end{array}$ \\
\hline \multicolumn{7}{|c|}{ Podcast as a facilitating tool } \\
\hline 1. & $\begin{array}{l}\text { I believe that podcast can be } \\
\text { used as a complementary tool } \\
\text { with traditional teaching of } \\
\text { EFL at the undergraduate level } \\
\text { in Bangladesh. }\end{array}$ & & & & & \\
\hline 2. & $\begin{array}{l}\text { Podcast can offer an enormous } \\
\text { opportunity to enhance } \\
\text { teaching-learning experience. }\end{array}$ & & & & & \\
\hline 3. & $\begin{array}{l}\text { It is possible to get an } \\
\text { exposure to native/native-like } \\
\text { situational and academic } \\
\text { English environment with the } \\
\text { use of podcasting. }\end{array}$ & & & & & \\
\hline 4. & \begin{tabular}{|ll}
$\begin{array}{l}\text { Learning could be made } \\
\text { entertaining }\end{array}$ & $\begin{array}{l}\text { be } \\
\text { integrating }\end{array}$ \\
podcasting with it. &
\end{tabular} & & & & & \\
\hline \multicolumn{7}{|c|}{ Effectiveness of Podcasting } \\
\hline 5 & $\begin{array}{l}\text { My performance could be } \\
\text { improved with the integration } \\
\text { of podcasting into the } \\
\text { curriculum. }\end{array}$ & & & & & \\
\hline 6. & 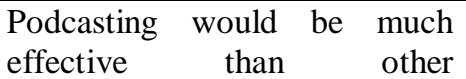 & & & & & \\
\hline
\end{tabular}




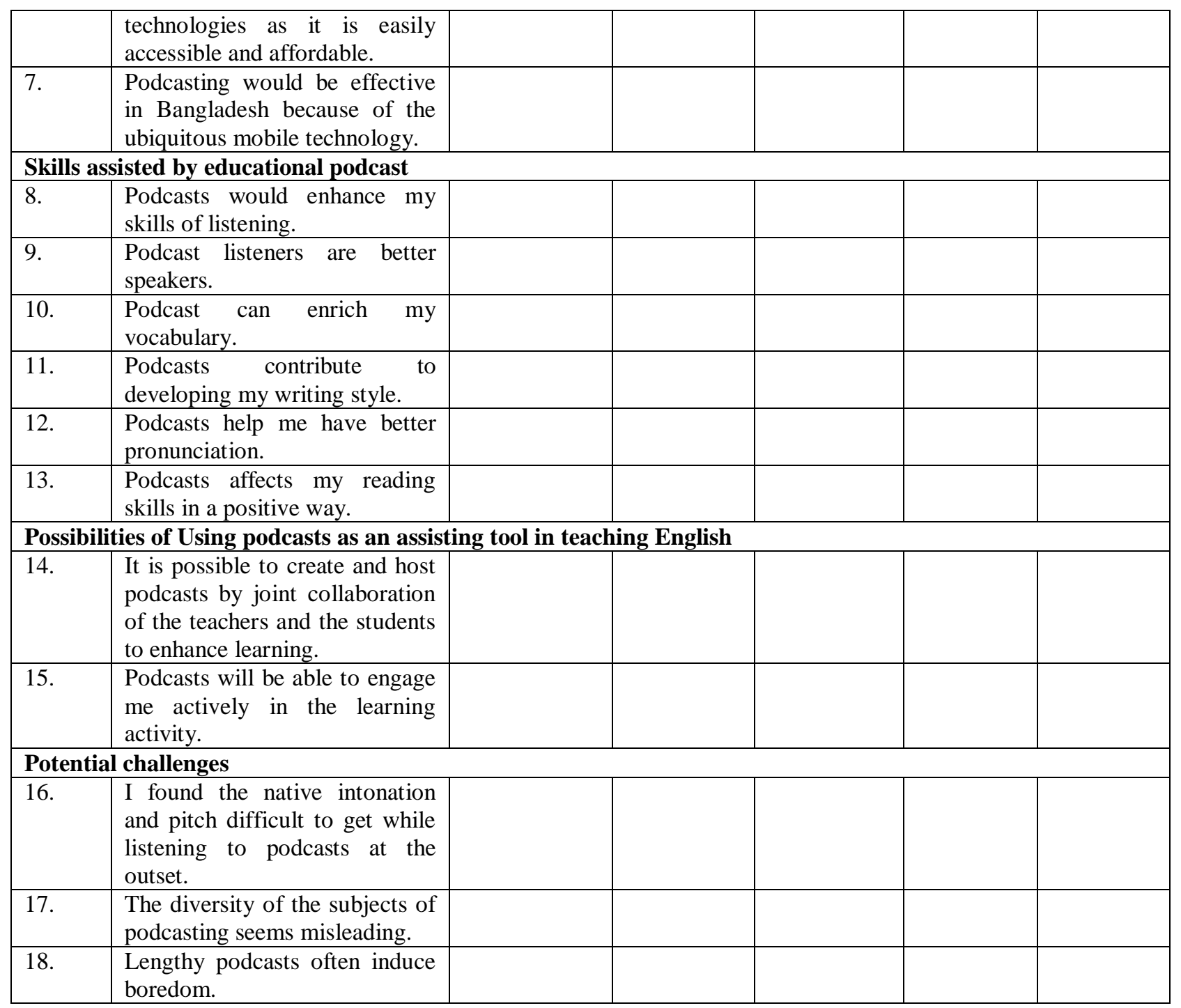

